\title{
A diéta és a fizikai aktivitás együttes hatása
}

\section{Combined diet and physical activity is better than diet or physical activity alone at improving health outcomes for patients in New Zealand's primary care intervention}

Ismerteti: Kocsis Éva $\square$

Pécsi Tudományegyetem, Általános Orvostudományi Kar, Orvosi Népegészségtani Intézet

Szerzők: Catherine Anne Elliot, Michael John Hamlin

Megjelenés: BMC Public Health, 2018; 18:230doi: https://doi.org/10.1186/s12889-018-5152-z

Beküldve: 2018. 05. 07.

doi: 10.24365/ef.v59i4.289

Kulcsszavak: alapellátás-szintű beavatkozás, fizikai aktivitás, diéta, táplálkozás, betegségmegelőzés

Keywords: primary care intervention, physical activity, diet, nutrition, disease prevention

\section{ÖSSZEFOGLALÁS}

Új-Zélandon évek óta múködik a „Zöld Vény” (Green Prescription) elnevezésű program az alapellátásban, ahol személyre szabott mozgásprogramot írnak elő kardiorespiratorikus, metabolikus, mozgásszervi vagy pszichológiai tünetekkel, vagy azok kombinációjával rendelkező betegek számára. A szerzők a Zöld Vény program résztvevőiből reprezentatív mintát vettek, a vizsgálatba 1488 főt választottak be (29\% férfi, $\geq 60$ év: 46\%), reprezentálva a kisebbségeket, a maori és óceániai őslakosokat is. A tanulmány célja annak elemzése, hogy a fizikai aktivitás növelése és az étrendi változtatás milyen hatást gyakorolnak a programban résztvevő betegek egészségi állapotára.

A vizsgálatban résztvevőket megkérdezték az egészségmagatartásuk változásáról: hogyan változott a programban való részvételt követően a fizikai aktivitásuk, illetve változtattak-e az étrendjükön. Ezen viselkedésváltozások alapján 4 csoportra osztották őket: 1. csak a fizikai aktivitást növelők csoportja; 2. csak az étrenden változtatók csoportja; 3. a fizikai aktivitást is növelő és az étrendjükön is változtatók csoportja; 4. kontrollcsoport, akik semmin sem változtattak a javaslatok ellenére. A résztvevőket a kapcsolódó egészségi problémáik alapján 7 alcsoportba sorolták: metabolikus ( $n=1192)$, mozgásszervi ( $n=627)$, pszichés $(n=447)$, és alvási problémák ( $n=253)$, légzési nehézségek $(n=243)$, esés megelőzés $(n=104)$, dohányzás $(n=67)$.

A legtöbben súlyproblémával ( $n=886)$, magas vérnyomással és stroke kockázattal ( $n=424)$, arthritisszel $(n=397)$, valamint hátfájással $(n=382)$ küzdöttek. A programba való bekerülést követően tapasztalt javulást az egészségi állapotban 15 féle mutatóval mérték a szerzők, leggyakoribbak a fogyás ( $n=618,46 \%$ ), könnyebb légzés ( $n=430$, $32 \%)$ és kevesebb stressz $(n=419,31 \%)$ voltak. A csak a táplálkozáson változtatók csoportjában a betegek a 15 féle mutató közül 3-nál értek el javulást, a csak a fizikai aktivitást növelők csoportjában 15 változóból 6-nál, míg a fizikai aktivitást növelők és étrendjükön egyszerre változtatók csoportjában a 15 változóból 11-nél voltak jobbak az eredmények a kontrollcsoporthoz képest (nemre és életkorra kontrollálva). A metabolikus alcsoportban, azon betegeknél, akik csak az étrendjükön változtattak, 7,2-szer nagyobb esély volt a súlycsökkenésre, 2,4-szer nagyobb esély a vérnyomás csökkenésére és 3,5-ször nagyobb esély a 
koleszterinszint csökkenésére a kontrollcsoporthoz képest. Akik a fizikai aktivitásukat növelték, 5,2-szer nagyobb eséllyel fogytak a kontrollcsoporthoz viszonyítva, míg akik mind az étrendjükön, mind a fizikai aktivitásukon változtattak, 17,5-szer nagyobb esélyIyel tapasztaltak testtömegcsökkenést. Ez utóbbi-a testmozgást növelö és étrenden is változtató csoportban nagyobb volt az esély a vérnyomás csökkenésére $(O R=3,2)$, a vércukor $(O R=3,8)$ és a koleszterinszint csökkenésére $(O R=3,5)$, valamint a gyógyszerszedés csökkentésére $(O R=4,2)$ is a kontrollcsoporthoz képest.
Annak ellenére, hogy hivatalosan a táplálkozási tanácsadás nem képezte a Zöld Vény program részét, a résztvevők 55\%-a a fizikai aktivitás mellett az étrenden is változtatott. A szerzők szerint a jövőben érdemes vizsgálni, hogy a fizikai aktivitás betölthet-e kapuszerepet a program résztvevőinél az étrendi változás elősegítésére.

Összefoglalásként a szerzők javasolják, hogy a Zöld Vény programba mielőbb építsék be a dietetikus által vezetett étrendi tanácsadást is, hiszen a komplex beavatkozás a társbetegségek előfordulását is csökkentheti a súlyvesztésen felül.

\section{TANULSÁGOK A HAZAI SZAKEMBEREK SZÁMÁRA}

A vizsgálat eredményeit többféleképpen is lehet interpretálni: 1. A metabolikus problémák nagyobb mértékú javulását lehet elérni, ha a (Zöld Vény programban résztvevő) betegek a fizikai aktivitás növelése mellett a táplálkozáson is változtatnak; 2. A fizikai aktivitás ösztönzésére irányuló program a táplálkozásban is eredményezett változást; 3. A táplálkozás és a testmozgás együttes hatására bekövetkező javulás az egészségi állapotban nagyobb mértékű, mint ami külön-külön elérhető. 